\title{
Den næste præsident
}

Richard Holbrooke

\section{Den frie verdens kommende leder vil skulle beherske en skræmmende dagsorden}

Amerikas næste præsident kommer til at overtage ledelsen af en nation, der stadig er verdens stærkeste, en rig nation, som fortsat giver løfter om en stærk dynamik, og hvis befolkning bliver stadig mere mangfoldig. En nation, der før har kunnet, og som igen må kunne inspirere, mobilisere og lede verden.

Men samtidig vil den næste præsident på sin tiltræedelsesdag også overtage et vanskeligere sæt af internationale problemer end nogen af sine forgængere, i al fald siden Anden Verdenskrigs slutning. Under disse omstændigheder vil hans kerneudfordring være intet mindre end at genskabe en sans for nationens højere formål og styrke efter en periode med forvildelse, nedgang og katastrofale fejltagelser.

Han vil blive nødt til at udvikle en ny politik inden for den bredest tænkelige spændvidde af udfordringer, indenrigs- som udenrigspolitiske. Han vil blive nødt til at genopbygge konstruktive arbejdsrelationer med venner og allierede. Han må genoplive en vaklende økonomi, tæmme et budget, der er overskyllet af rødt blæk, reducere energiafhængigheden og tage hul på et helt nyt kapitel, når det gælder det i sandhed eksistentielle spørgsmål om klimaforandringer, ligesom han må sætte ind imod den voksende fare for atomvåbenspredning, forbedre det nationale forsvar imod globale terrorister og samtidig øge presset på al-Qaeda, navnlig i Pakistan, og, selvfølgelig, stå i spidsen for to krige på samme tid.

For at gøre fremskridt på en så frygtindgydende agenda må præsidenten beherske og kontrollere det uhæmmet voksende og besværlige forbundsstatslige bureaukrati, der altid søger at modstå forandringer og til tider er dysfunktionelt. Han vil også blive nødt til at ændre forholdet mellem den udøvende og den lovgivende magt efter års uforsonlige politiske slagsmål.

På næsten alle områder vil støtte fra Kongressen blive afgørende for hans succes. 
Lige så afgørende er det at sikre støtte fra offentligheden, hvilket vil kræve, at den næste præsident, mere effektivt end sine forgængere, forstår at mobilisere hjælp fra den private sektor, den akademiske verden, ngo'er og civilsamfundet som helhed.

\section{Et ekstraordinært job}

At være præsident for De Forenede Stater er det mest ekstraordinære job, der nogensinde er udtænkt. Det er en position, som er blevet genstand for håb og for drømme - og til tider for frygt, frustration og vrede hos mennesker verden over. Forventninger om, at præsidenten kan løse ethvert problem er åbenlyst urealistiske, og ikke desto mindre er sådanne forventninger en virkelighed, han vil være nødt til at forholde sig til.

En succesrig præsident må kunne definere meningsfulde, og dog gennemførlige mål, lægge dem klart frem for nationen og verden og realisere dem i kraft af lederevner, som vil blive afprøvet imod et pres, som ingen, der ikke har bestredet dette job, vil kunne forestille sig.

En reaktiv og passiv ledelsesstil vil ikke blive nogen succes, ligesom præsidenten må afholde sig fra at love løsninger, han ikke kan levere. $\mathrm{Og}$ fra at handle med konsekvent ringeagt for, hvad Uafhængighedserklæringen betegner som "en anstændig respekt for menneskehe- dens anskuelser”. Skønt ikke alle de politikområder, som den nye præsident overtager ansvaret for, vil kræve forandringer, vil alle væsentlige blandt dem kræve omhyggelige genovervejelser. I mange tilfælde vil nye politikker og nye folk, som er loyale over for præsidenten og i stand til at mobilisere det permanente bureaukrati, være nødvendige.

Men en omfattende national sikkerhedspolitik er mere end en samling af individuelle positioner. En sammenhængende vision for De Forenede Staters rolle i verden må bygge på dets vedvarende nationale interesser, dets værdier og en realistisk vurdering af dets evner og prioriteringer.

End ikke verdens mest magtfulde nation kan forme enhver begivenhed og udvikling i henhold til egne præferencer. Den tid, da et enkelt ord såsom 'inddæmning' kunne definere amerikansk udenrigspolitik, vil ikke komme tilbage til denne verden med mange spillere og mange, mange problemområder.

Alligevel er der behov for at definere et bredt overgribende koncept om De Forenede Staters nationale interesser. (Bush-æraens fokus på 'den globale krig mod terror' var på en gang for snæver og for bred.)

For at gengive De Forenede Stater dets rette rolle som verdensleder, er der to svaghedsområder, som må udbedres: den indenlandske økonomi og De Forenede Staters ry i verden. Skønt økonomien i reglen be- 
handles som et indenrigspolitisk politikområde, er en genoplivelse af den af lige så afgørende betydning for nationens langsigtede sikkerhed, som det er at holde USA's militære styrke ubestridelig. Dette vil kræve mere end et cyklisk opsving.

For at reparere økonomien på længere sigt vil en ny national politik om energi og klimaforandringer være altafgørende. $\mathrm{Og}$ at genoprette respekten for amerikanske værdier og ledelse er essentielt - ikke kun fordi det er dejligt at være populær, men fordi respekt er en forhåndsbetingelse for legitimt lederskab og vedvarende indflydelse.

Præsidenten bør sætte ind over for begge disse problemer så tidligt som muligt for at styrke sin hånd, når han skal løfte presserende strategiske udfordringer, herunder dem, der vedrører de fem nabolande, som befinder sig i centrum af den kritiske halvmåne, som direkte truer De Forenede Staters nationale sikkerhed - Tyrkiet, Irak, Iran, Afghanistan, Pakistan.

Nogle få hurtige initiativer, som fuldt og helt ligger inden for hans beføjelser, vil kunne give øjeblikkelig effekt. Det mest tungtvejende af disse udspil vil være at udstede et utvetydigt og officielt forbud imod tortur og lukke interneringscentret ved Guantánamo Bay på Cuba, som nu rummer 260 fanger.

Fordi Bush-regeringen nøjedes med kun at straffe dem, som befandt sig længst nede i kommando- kæden i Abu Ghraib, har skaden på De Forenede Staters renommé været enorm og vedvarende - De Forenede Staters fjender slår fortsat mønt heraf. Præsidentielle direktiver, der gør klart, at den amerikanske regering ikke kan tolerere eller bifalde tortur er nødvendige for at sætte et klart skel mellem den nye regering og denne belastende arv fra dens forgængere.

Hvad Guantánamo angår, indvender Bush-regeringens apologeter (foruden flere advokater), at det kan blive vanskeligt at lukke stedet. Nuvel, mange ting i livet er vanskelige. Guantánamo må ikke også blive den næste præsidents møllesten om halsen.

At lukke lejren, uanset hvor vanskeligt det så måtte være, er ikke blot ønskeværdigt - det er bydende nødvendigt.

\section{En ny faktor}

Historien står aldrig stille. Alligevel findes der et mønster, som kommer ret tæt på at være en historisk lovmæssighed: I det lange løb har store nationers opkomst, storhed og fald i første række været afhængig af graden af deres økonomiske styrke. Rom, det kejserlige Kina, Venedig, Frankrig, Nederlandene, Portugal, Storbritannien - alle havde deres storhedstid, og international tilbagegang fulgte ubønhørligt i kølvandet på deres økonomiske nedture.

Fra sidste halvdel af 1800-tallet var 
intet så vigtigt for De Forenede Staters opkomst som landets spektakulære økonomiske vækst. Denne vækst blev i bogstaveligste forstand næret af billig, hjemmeudvunden olie. De Forenede Stater overvandt altid sine periodiske økonomiske nedture, selv Den Store Depression. Det er derfor forståeligt, hvis amerikanerne, der af natur er optimister, uden videre går ud fra, at nationens aktuelle økonomiske vanskeligheder blot er endnu et midlertidigt cyklisk tilbageslag.

Men en ny faktor er dukket op, som ikke ligner noget USA nogensinde tidligere har stået overfor. Med en råoliepris der er fire gange højere end, hvad den var for fire år siden, er amerikanerne vidne til eller rettere: bidrager de til - historiens største overførsel af velstand fra en gruppe af nationer til en anden. Politikere og pressen sætter forståeligt fokus på det hjemlige pres, der er frembragt af den høje pris på olie - 'smerten ved benzinpumpen'. Men de store langsigtede geostrategiske implikationer af denne velstandsoverførsel, der indtil videre har været stort set negligeret, vil også kræve den næste præsidents opmærksomhed.

Følgende betragtning fra den ansete olieekspert Daniel Yergin kan være instruktiv: De Forenede Stater konsumerer over 20 millioner tønder olie om dagen, hvoraf 12 millioner er importeret. Baseret på priser fra første halvdel af 2008, betyder dette, at USA overfører omkring 1,3 milliarder dollar til de olieproducerende lande hver eneste dag - det bliver på et år til 475 milliarder dollar (målt ud fra den seneste pris på 140 dollar per tønde råolie er beløbet langt højere).

De andre større forbrugere, herunder Kina, EU, Indien og Japan sender stadig større andele af deres rigdom til de olieproducerende lande, hvad der giver en samlet årlig overførsel på et godt stykke over 2,2 billioner dollar. Og tallene stiger med fortsat hast.

Lad os antage, at de høje oliepriser fortsætter i lad os sige yderligere et årti - et dystert, men ikke urealistisk scenario i lyset af den lange omstillingsfase, det vil kræve at vænne forbrugernationerne af med deres kostbare vane.

Nogle af disse producentnationer har politiske agendaer, der afviger meget fra De Forenede Staters, Europas og Japans. Grupper af olierige nationer med målsætninger, der står i modsætning til De Forenede Stater og dets europæiske allierede vil blive mere almindelige og handle med større drist. Flere penge vil komme til rådighed til at finansiere farlige, ikke-statslige aktører, som søger at ødelægge Israel eller destabilisere dele af Afrika eller Latinamerika. Eller angribe De Forenede Stater.

Der findes allerede et velkendt eksempel på dette, selv om det ikke ser ud til at Vesten har lært noget af det: Saudi-Arabien som, skønt det 
længe har samarbejdet med Washington om at forøge sit olie-output og holde priserne inden for et acceptabelt niveau, på samme tid har tilladt milliarder af (demonstrativt ikke-statslige) dollar at indgå i opbyggelsen af ekstremistiske religiøse skoler og til finansiering af terroristorganisationer, herunder al-Qaeda.

Der vil blive flere tilfælde af lignende komplicerede dobbeltspil i fremtiden: Tvivler nogen på, at den aktuelle selvhævdelse på den internationale scene fra fx Irans, Ruslands og Venezuelas side kommer fra de økonomiske muskler, der ledsager deres voksende petrodollarreserver? (Venezuela bruger nu fem gange så meget som De Forenede Stater på at yde bistandshjælp til resten af Latinamerika.)

\section{Klimaforandringerne}

Samtidig har problemet med klimaforandringer nået et niveau, som i mange forskeres øjne truer planeten. Mange hylder den antagelse, at der kun er et årti tilbage at handle i for at undgå et katastrofalt vendepunkt, som i modsat fald vil indtræde et eller andet tidspunkt omkring midten af århundredet.

Selv da tidligere vicepræsident $\mathrm{Al}$ Gore rejste kloden rundt for at råbe vagt i gevær, spildte Bush-regeringen syv et halvt år uerstattelige år ved at nægte at forholde sig til problemet.

Der var ikke megen forståelse for den akut nødvendige handlekraft i denne regering eller blandt dens allierede i Kongressen. De var imod næsten alt andet end frivillige energispare-foranstaltninger - lige indtil priserne ved benzinpumpen nåede 4 dollar per gallon (ca. 5,50 kr. per liter, red.).

Det var først i slutningen af 2007 og efter et enormt politisk pres, at Bush-regeringen omsider indvilgede i den første skærpelse af standarderne for brændstof-effektivitet i 32 år. (På dette tidspunkt havde Gore, passende nok, vundet Nobel-prisen). Så, på G8-topmødet i 2008, gik George W. Bush med til en vagt formuleret og dybest set meningsløs målsætning om at 'stræbe efter' at reducere kulstofudledningerne.

Over tid vil stærkere energisparetiltag sammen med investeringer i nye teknologier utvivlsomt blive taget $\mathrm{i}$ anvendelse. Men hvis olie- og gaspriserne falder fra deres nuværende boblelignende niveau, vil forbruget vokse på ny. På den anden side: Hvis priserne forbliver på et højt niveau, vil forbruget falde, men så vil De Forenede Stater og dets nærmeste allierede fortsætte med at bløde petrodollars.

Uanset hvordan det måtte gå, vil kloden i fraværet af en effektiv energipolitik lide under den fortsatte opvarmning.

Tørke og hungersnød vil blive værre i nogle af Jordens fattigste regioner, fødevarepriserne vil fortsætte med at stige og hele folkegrupper 
vil forlade områder, der ikke længere er dyrkbare. Gletsjere og iskapper vil smelte hurtigere, havenes vandstand vil stige og flere dyre- og plantearter vil udd $\varnothing$.

Bush-regeringens forsømmelse af disse spørgsmål overstiger langt det forbløffende - den er, på sin egen måde, lige så chokerende som regeringens præstationer i Afghanistan og Irak.

De to præsidentkandidater, senator Barack Obama (Demokrat, Illinois) og senator John McCain (Republikaner, Arizona) siger begge, at de tager klimaforandringerne alvorligt. Men en undersøgelse af deres positioner i spørgsmålet afslører betydningsfulde forskelle.

Obama har en langt mere omfattende plan med ambitiøse målsætninger om emissionsreduktioner og en markedsbaseret mekanisme, som samler bred støtte blandt økonomer af både venstre- og højreobservans, ligesom Obamas plan rummer væsentligt større investeringer end McCains plan om nye teknologier, som kan hjælpe til at fremme disse mål.

McCain lægger vægt på at fjerne miljørestriktioner på olieboringer $\mathrm{i}$ amerikanske naturreservater og territorialfarvande. Dette er næppe en brugbar langsigtet løsning, for selv om der måtte blive fundet nye felter, vil de ikke få nogen effekt på energiforsyningen i mindst et årti og vil intet udrette til gavn for energibesparelse eller indsatsen imod klimaforandringer.

\section{Behov for konsensus}

Bestræbelserne på at udvikle effektive politikker til imødegåelse af energi- og klimaforandringer vil kræve en national konsensus om situationens alvor og en handlingsplan, der pålægger alle parter kompromiser og ofre - ofre, som normalt forbindes med krig - alt sammen uden at undergrave den økonomiske vækst.

Som advarsel om, hvor galt det kan gå, er det værd at erindre om præsident Jimmy Carters lidenskabelige, men mislykkede forsøg på at samle nationen i en tv-tale i bedste sendetid i april 1977. Iført en cardigan, der skulle afstedkomme talrige drillerier, udtalte han, at hans energi-uafhængighedsprojekt ville blive "det moralske modstykke til krig" (moral equivalent of war). Da en eller anden påpegede, at forbogstaverne $\mathrm{i}$ det udtryk lød meow (mjav), havde medierne en fantastisk dag og ignorerede indholdet af Carters forslag. En sand national debat blev udskudt i 30 år.

En af Ronald Reagans første handlinger som præsident var at fjerne de solpaneler, Carter havde ladet installere på taget af Det Hvide Hus.

Energiafhængighedens og klimaændringers dobbelt udfordring giver mulighed for et gennembrud i forholdet mellem de to største nationer i verden i dag, som tillige er verdens værste forurenere. Tilsammen producerer Kina og USA næsten 50 procent af verdens kulstof-emissio- 
ner. I de seneste år har Kina overhalet USA som verdens største forurener. I 2007 stammede to tredjedele af den samlede vækst i den globale udledning af drivhusgasser fra Kina, ifølge nederlandske Environmental Association, som desuden anslår, at Kina nu udsender 14 procent flere klima-opvarmende gasser end USA gør.

Opgør man det på per capita-basis, er der dog stadig en afgrund til forskel, som enhver kineser ivrigt vil påpege: USA producerer 19.4 tons kuldioxid per person om året, Kina (5.1 tons) halter ikke blot langt efter USA, men også efter Rusland (11.8 tons) og de vesteuropæiske lande ( 8.6 tons). Indien befinder sig langt nede på listen med blot 1.8 tons per capita.

Bestræbelserne for at formulere en ny international traktat om klima-forandringer, der skal erstatte Kyoto-protokollen ved dens udløb i 2012, står alle steder i stampe. En ny aftale skal angiveligt være færdig og klar til at blive underskrevet i $\mathrm{K} \varnothing$ benhavn i slutningen af 2009. Om dette vil ske, må anses for tvivlsomt.

Da hverken Kina eller USA spiller nogen ledende rolle i forhandlingerne, advarer mange medlemmer af Kongressen om, at der ikke er større muligheder for, at Senatet vil ratificere en København-aftale næste år, end der var for at det ville godkende Kyoto-protokollen i 1990'erne (med andre ord: ingen) - medmindre da, at som minimum Brasili- en, Kina, Indien og Indonesien skulle blive enige at definere grænser for deres kulstofemissioner. $\mathrm{Og}$ uden Kina og USA, vil værdien af en sådan traktat, skønt reel nok, trods alt være begrænset.

\section{Uløselig hårdknude}

Vi står over for en tilsyneladende uløselig hårdknude: De store vækstøkonomier vil ikke gå med til en traktat, der indeholder meningsfulde grænser for deres emissioner. $\mathrm{Og}$ det amerikanske senat ikke vil ratificere en aftale, der ikke omfatter de samme vækstøkonomier.

Der er imidlertid en anden tilgang, der bør overvejes uden dermed at opgive København-processen, nemlig at indgå separataftaler, hvor nationer gruppevis går sammen om at håndtere specifikke dele af det overordnede problem. I sådan en samling af aftaler, vil der være større muligheder for et reelt amerikansk-kinesisk samarbejde.

Frem for alt vil disse to nationer kunne indgå bilaterale aftaler om fælles projekter inden for energibesparelse og udvikling af ny klimaskånsom teknologi. Målsætningerne, som begge parter kan have gavn af at indfri, vil være en højere energieffektivitet og en reduktion i kulstofemissioner i begge lande.

Japan, verdens mest effektive energi-forbruger - og en uundværlig allieret for USA - kunne også deltage i sådanne arrangementer. Ja- 
pan har meget at lære begge nationer og har allerede bilaterale aftaler om teknologi-udveksling med Kina.) Fra kulfiltre og anden ren kul-teknologi til sol-og vindenergi er der et stort uudnyttet potentiale i fælles projekter og teknologideling - men endnu ingen institutionaliserede amerikansk-kinesiske rammer, der kan hjælpe dem frem.

På en rejse til Kina for nylig foreslog jeg sådanne bilaterale aftaler over for højtstående kinesiske embedsmænd, der da også udviste interesse og vilje til uofficielt at overveje ideen gennem ikke-statslige kanaler. Deres bekymring som de udtrykte helt åbenhjertigt, var at enhver energiplan, som Vesten måtte foreslå, kunne blive opfattet som et nyt kneb for at bremse Kinas økonomiske vækst.

Uanset om denne frygt har hold i virkeligheden eller ikke, så er den dybfølt og deles også af Indien og de andre nye store vækstøkonomier, hvilket der er brug for at forstå og tage høje for.

Men måske er mulighedernes vindue allerede ved at åbne lidt på klem: Wang Qishan, Kinas magtfulde vicepremierminister, der har ansvar for handel og finanser, opfordrede for nylig offentligt til at oprette fælles forskningslaboratorier for vedvarende energi og forureningsreducerende teknologier. "Et stærkere samarbejde mellem de to lande inden for energi og miljø," skrev han i Financial Times den 16. juni, "vil gøre det muligt for Kina at indrette sig mere hensigtsmæssigt på energiog miljømæssige udfordringer og også skabe store forretningsmuligheder og nydelige afkast for de amerikanske investorer."

Skønt holdt i en forsigtig sprogbrug er dette et uventet og velkomment signal fra en af Kinas øverste embedsmænd. Den næste regering bør ikke ignorere det. En energisk opfølgning af dette udspil vil ikke blot have relevans for indsatsen mod et af verdens mest presserende problemer. Det vil også åbne en ny dør for et samarbejde inden for verdens vigtigste bilaterale forbindelse.

\section{Ligheder og forskelle}

I betragtning af den udbredte utilfredshed blandt amerikanerne med nationens nuværende tilstand er det næppe overraskende, at både Obama og McCain har søgt at fremhæve de forandringer, de hver især vil gennemføre. Begge har givet udtryk for, at de ville lægge større vægt på Afghanistan, der i første omgang var en succeshistorie for Bush-regeringen, men siden dramatisk har udviklet sig til det værre som følge af forsømmelser og en forkert og dårlig ledelse.

Begge kandidater har lovet at styrke De Forenede Staters forhold til dets NATO-allierede. Begge har udtrykt bekymring - om end i meget forskellige formuleringer - over Ruslands seneste adfærd, navnlig i 
Georgien. (McCain er dog gået for vidt med meget konfrontatoriske udtalelser, herunder en opfordring til at smide Rusland ud af G8-gruppen af højt industrialiserede lande et skridt, han sikkert udmærket ved, aldrig ville blive godkendt af de øvrige seks G8-medlemmer og i sig selv en dårlig idé.)

Begge har lovet at genopbygge de væbnede styrker og bedre pleje til de sårede fra Afghanistan og Irak. Begge har forpligtet sig til at støtte og forsvare Israel. (Selv om begge har sagt, at de ville lukke interneringslejren på Guantánamo og forbyde tortur, viste der sig alligevel en signifikant forskel i en nylig senatsafstemning: Obama støttede, og McCain stemte imod at indføre lovbefalede krav om at pålægge CIA de samme forhørsregler, som gælder for militæret og som er fastslået i $U S$ Army Field Manual.)

Det er forskellene mellem Obama og McCain, der er virkelig afslørende og giver en vigtig indsigt i de to mænds værdier, personlige stil og $\mathrm{i}$ deres stærkt divergerende holdninger til diplomatiets rolle og i væsensforskellige visioner for USA. Uanset om det gælder klimaforandringer, energipolitik, Afrika, Cuba, eller Iran, er Obamas udspil fremadrettede. Han er fortaler for at tilpasse gamle og stillestående politikker til nye og skiftende forhold. Han understreger behovet for diplomati som den bedste metode til at øge USA's magt og indflydelse.
Når det gælder handelspolitik, beskylder McCain måske nok Obama for neoprotektionisme. Men realiteten er snarere den, at Obama argumenterer for bedre handelsaftaler, der inddrager hensyn til elementer som arbejdsløn og miljønormer forbedringer, som vil kunne give sådanne aftaler større indenlandsk støtte.

\section{Demokratiernes forbund}

I modsætning hertil er McCains dristigste forslag hverken nyt eller originalt: Hans vage League of Democracies lyder fx som en udbygning af organisationen Demokratiernes Fællesskab, som blev skabt af den tidligere udenrigsminister Madeleine Albright, og som stadig findes, men stort set er blevet ignoreret af Bushregeringen.

Selv om McCain hævder, at hans forbund "ikke skal erstatte de Forenede Nationer" så foreslår han udtrykkeligt, at dette skal kunne tage kollektive skridt, når FN ikke kan eller vil. "Den nye Demokratiernes Forbund," sagde han sidste år, “... skal kunne handle, hvor FN ikke handler for at mindske menneskelig lidelse i områder som Darfur og lægge samordnet pres på tyranner i Burma og Zimbabwe, med eller uden Moskvas og Beijings godkendelse."

McCain kalder dette for "den sandeste form for realisme". Uanset hvad McCain siger, vil hans 'for- 
bund' i modsætning til det forum, som Albright skabte, af alle parter blive udlagt som et forsøg på at skabe en rival til FN.

De seneste samtaler jeg har ført med højtstående embedsmænd i flere af verdens førende demokratier, har bekræftet mig $i$, at end ikke USA's nærmeste allierede - endsige verdens største demokrati, Indien vil støtte en ny organisation med et sådant mandat.

\section{FN's rolle}

FN er blevet undermineret og underfinansieret gennem de sidste otte år, hvilket ofte har gjort det svagere og mere modtageligt over for antiamerikanske holdninger. FN er så afgjort en institution med store mangler. Men den spiller en vigtig rolle i De Forenede Staters udenrigspolitik, og kan, hvis den anvendes på rette vis, fremme USA's nationale interesser og spille en mere effektiv rolle i fredsbevarende operationer i sådanne vanskelige områder som Sudan. Men FN kan kun være så stærk som dets største bidragyder (som også er et stiftende medlem), USA, ønsker FN skal være.

Obama vil forbedre og reformere organisationen på en måde, som vil tjene USA's interesser og begynde med at anmode Kongressen om at betale de restancer, der er vokset endnu engang, under Bush, til over 1 milliard dollar (en amerikansk gæld af samme størrelse blev afbe- talt efter en aftale, der blev indgået i Clinton-regeringens sidste år). At oprette en helt ny organisation i stedet for at gøre en fornyet indsats for en seriøs FN-reform vil modarbejde de selv samme målsætninger, som McCain siger, at han vil fremme.

I sin tale om nuklear spredning på University of Denver den 27. maj sagde McCain, at han vil genoverveje sin årelange modstand mod Traktaten om Atomprøvestop, hvis en genforhandling kan "overvinde de mangler, der forhindrer den i at træde i kraft" - en vag og løst formuleret forhåndsbetingelse.

Obama, derimod, har erklæret sig som helhjertet tilhænger af denne vigtige traktat. Tilsvarende har Obama tilsluttet sig det mål om at eliminere alle atomvåben, som blev skitseret i en nu berømt artikel af tidligere udenrigsminister George Shultz, tidligere forsvarsminister William Perry, tidligere udenrigsminister Henry Kissinger, og tidligere senator Sam Nunn. McCain har demonstrativt nægtet at gøre dette.

Ser man på disse og andre forskelle, er det klart, at de amerikanske vælgere har fået tilbudt to forskellige opfattelser af De Forenede Staters rolle i verden og to forskellige holdninger til diplomati. I de fleste spørgsmål, med den vigtige undtagelse af klimaændringer, enten støtter McCain Bush-regeringen eller står for en hårdere linje end denne. (For eksempel gav han udtryk for dyb skepsis omkring den delvise af- 
tale, som præsident Bush offentliggjorde sidst i juni om et stop for Nordkoreas atomvåbenudvikling.)

Selv om McCain foretrækker at betegne sig selv som en 'realist', eller i senere udtalelser: en 'realistisk idealist', er det, når man anlægger et bredt perspektiv på hans holdninger umuligt at se bort fra de mange slående paralleller imellem ham og de såkaldte neokonservative (hvoraf mange er højlydt erklærede og åbenlyse støtter af hans kandidatur).

\section{Uenigheden om Irak ...}

Selvfølgelig har ingen af holdningsforskellene mellem Obama og McCain en tilnærmelsesvis så stor betydning som deres uenighed om Irak og Iran. De Forenede Staters politik over for disse to lande vil mere end noget andet politikområde forme synet på den nye præsident, ja i visse henseender kan det amerikanske præsidentvalg udlægges som en folkeafstemning om Irak.

Når McCain siger, at USA er i Irak for at vinde, så mener han det - ganske uanset hvilke omkostninger krigen måtte få og hvor længe den måtte vare. Intet andet emne engagerer ham så dybt eller følelsesmæssigt, og hans følelser udspringer ikke af politiske kalkulationer, men af dyb personlig overbevisning. Som han ser det, er den seneste nedgang i de amerikanske og irakiske tabstal beviset på, at USA er ved at vinde krigen.
I skrivende stund har han dog endnu ikke signaleret, at den meget velkomne forbedring af situationen kan føre til betydelige troppetilbagetrækninger i 2009 ud over den allerede bebudede tilbagekaldelse af de ekstrastyrker, som blevet indsat under 'Optrapningen' (the surge). Han har gentagne gange gjort det klart, at han hellere vil lade de amerikanske tropper blive i Irak på ubestemt tid frem for at løbe de risici, han mener, vil være forbundet med store reduktioner. Risiciene og omkostningerne ved den fortsatte udstationering har han aldrig villet erkende.

Derimod mener Obama, at en militær sejr, som Bush og McCain forstår den, ikke er mulig - en vurdering, der deles af den amerikanske militærledelse i Irak. Det er hans opfattelse, at det vil få uacceptable omkostninger for USA at skulle forpligte sig tidsubegrænset til at fortsætte en krig, der aldrig skulle have været startet. Obama konkluderer, at det af hensyn til USA's overordnede interesse er nødvendigt at begynde at trække amerikanske landbaserede kamptropper tilbage i et støt, men, understreger han, 'forsigtigt' tempo.

Dette vil, forudser han, lægge langt større pres på de irakiske politikere for at nå de kompromiser, der er nødvendige for at stabilisere landet, end hvis man blot lader tropperne blive der. Idet han fremhæuer diplomatiet som en uundværlig be- 
standdel i USA's magt, har Obama ligeledes opfordret til en omfattende indsats for at inddrage alle Iraks naboer i en regional diplomatisk og politisk indsats for at stabilisere landet.

McCain hævder heroverfor, at hans modstanders holdning (som han og hans tilhængere fejlagtigt fremstiller som en 'forhastet tilbagetrækning') vil høste nederlag på tærsklen til sejr, opmuntre USA's fjender, og svække nationen.

Men han angiver ingen exit-strategi, ikke nogen klar definition på en opnåelig sejr og ingen plan til at fremme politisk forsoning i Irak. Hans politik er ikke meget andet end en opfordring til at fortsætte krigen på grund af de risici, der er forbundet med at forsøge at bringe den til ophør.

En sådan negativt defineret målsætning er ikke nogen tilstrækkelig begrundelse for at sætte endnu flere amerikanske liv på spil.

Nogle af McCains modstandere har undertiden forvansket hans holdning på et centralt punkt: Han har aldrig sagt, at USA måske kan blive nødt til at kæmpe i Irak i hundrede år. Men hvad han sagde, var lige så urealistisk og meget afslørende for hans tankegang. Med henvisning til Sydkorea, hvor 28.500 amerikanske soldater stadig står 55 år efter våbenhvileaftalen, erklærede McCain, at han var parat til at holde de amerikanske tropper i Irak i mindst lige så lang tid, hvis ikke længere, selv i hundrede år om fornødent.

En tilstedeværelse over så mange årtier, selv under fredelige forhold, er utænkelig i den fremmedfjendske og voldelige stemning i Mellemøsten. I sidste instans definerer McCain alle andre spørgsmål i forhold til Irak. "Resultatet af Irak-krigen," skrev han i denne publikation (Foreign Affairs, red.) i slutningen af sidste år, "vil berøre enhver af vore borgere i de kommende år." Det kan godt holde stik, men måske ikke på den måde, han tænker sig.

Obama vender McCains centrale argument på hovedet. "Moradset i Irak," skrev han, også i dette tidsskrift (Foreign Affairs, red.), "har gjort det umådeligt sværere at konfrontere og sætte ind mod de mange andre problemer i regionen - og har gjort mange af disse problemer betydeligt farligere."

På samme måde som McCain, der talte for krigen, endnu før den begyndte, har Obama været konsekvent hele vejen: Han var imod krigen fra starten. Han kendes selvfølgelig på sin hensigt om at indlede tilbagetrækning af kamptropper så hurtigt som muligt. Men fordi han anerkender vanskelighederne ved en tilbagetrækningsoperation, har han også sagt (uden at pressen har taget videre notits af det), at der er behov for at være yderst forsigtig på hvert et trin af denne proces.

Obama har sagt, at han vil forholde sig fleksibel med hensyn til, om der skal opretholdes en eller anden 
reststyrke og følges en nøjagtig tidsplan. "Denne omgruppering," skrev han, "vil kunne suspenderes midlertidigt, hvis Iraks regering ikke overholder de sikkerhedsmæssige, politiske og økonomiske retningslinjer, som den har forpligtet sig til. Men vi må erkende, at det i sidste ende kun er de irakiske ledere, der kan bringe reel fred og stabilitet til deres land."

Han tilføjede: "Den bedste chance, vi har for at efterlade Irak som et bedre sted, består i at presse de stridende parter [sunnierne og shiitterne] til at finde en varig politisk løsning. Og den eneste effektive måde, hvorpå dette pres kan udøves, er ved at begynde en gradvis tilbagetrækning af amerikanske styrker."

Tvisten mellem den irakiske regering og Bush-regeringen om en Aftale om Styrkernes Stilling (Status of Forces Agreement) kan belyse dette spørgsmål. Da Iraks premierminister insisterede på en tidsplan for USA's tilbagetrækning (og foreslog en tre til femårig justerbar tidsramme), gjorde både den nuværende regering og McCain indsigelse.

Hvorfor? Bush har ofte sagt, at USA ville forlade Irak, når dets tilstedeværelse ikke længere var ønsket. Nu gør han ophævelser imod en rimelig anmodning fra en suveræn stat, hvilket kun ser ud til at underbygge anklagen om, at USA søger en permanent tilstedeværelse i Irak.

Obama, derimod, kalder det irakiske signal for "en kæmpechance... for at begynde en gradvis omgruppering af vore kamptropper." I juli var der forlydender fremme om, at Bush-regeringen muligvis ville trække en til tre af de kampbrigader, der stadig var i Irak efter optrapningen, tilbage. Hvis dette har på noget sig, vil begge kandidater kunne hævde, at de havde ret; Obama kunne med rimelighed sige, at dette var hvad han havde opfordret til hele tiden, og McCain kunne sige, at dette viste berettigelsen af hans støtte til optrapningen.

\section{... og om Iran}

I hjertet af USA's geostrategiske udfordring ligger fem lande med tilst $\varnothing$ dende grænser: USA's NATO-allierede Tyrkiet, Irak, Iran, Afghanistan og Pakistan. I den kritiske halvmåne har mangel på sammenhæng præget amerikansk politik siden 2003 .

Dette femnationers område falder ind under tre forskellige regionale afdelinger i det amerikanske udenrigsministerium. Washington prædiker forskellige politikker om demokrati i nabolandene, hvilket forvirrer alle: Pres på Israel og palæstinenserne, for eksempel, for at lade terrororganisationen Hamas stille op ved det palæstinensiske valg $\mathrm{i}$ 2006 med katastrofale resultater til følge, men frafald til at fremme demokratiet i Egypten.

Der er ikke meget koordinering og integration af politikkerne i forhold til Afghanistan og Pakistan, 
selv om de to lande nu udgør en samlet krigsskueplads. Ingen samlet forståelsesramme ud over det vage begreb om 'den globale krig mod terror' - defineret på den måde, som måtte passe regeringens kortsigtede behov - har styret den amerikanske strategi. Forbindelserne til alle fem lande er blevet forværret.

Enhver seriøs politik vil nødvendiggøre, at De Forenede Stater beskæftiger sig med alle landene i denne region, herunder også Israel og Det Palæstinensiske Selvstyre, Libanon, Syrien og Saudi-Arabien. Dette indbefatter beklageligvis den meget ubehagelige realitet, der befinder sig midt i denne region: Iran.

Obama og McCain er enige om at bestræbelsen på at hindre Iran i at blive atomvåbenstat skal være en højt prioriteret målsætning. Begge vil stramme sanktionerne. Ingen af dem vil tage truslen om brug af magt fra bordet. Men derudover afviger deres betoninger og sprogbrug betydeligt.

Obama har gentagne gange givet udtryk for, at han er parat til at tage direkte kontakt til Iran, uanset på hvilket niveau han måtte finde det konstruktivt og ikke kun om nukleare spørgsmål, men også om Afghanistan, Irak og Irans støtte til terrororganisationer, herunder Hamas og Hizbollah (som Iran har udstyret med titusinder af raketter rettet direkte mod Israels midte).

McCain er ikke blot imod sådanne direkte samtaler, men har som bekendt også sagt, at det eneste, der er værre end en krig med Iran, ville være et nukleart Iran. Obamas ligefremme tilgang er blevet mødt med alarmerende udbrud fra McCain og hans tilhængere, som om bare selve tanken om at tale med sine fjender i sig selv var et tegn på svaghed, der lod antyde et nyt München 1938.

Denne holdning er i strid med årtiers amerikansk diplomati over for fjender, hvor amerikanske ledere, bakket op af styrke og magt, har kunnet indgå aftaler uden derved at svække USA's nationale sikkerhed. Diplomati er ikke det samme som eftergivenhedspolitik. Winston Churchill vidste dette og Dwight Eisenhower vidste det såvel som John F. Kennedy, Ronald Reagan og George H.W. Bush.

\section{Holdningen til dialog}

Denne særegne forskel mellem Obama, på den ene side og George W. Bush og McCain på den anden giver en vigtig indsigt i de bagvedliggende filosofier og værdier hos de to kandidater.

Selv om McCain og hans rådgivere nogle gange har overvejet mulighederne for at distancere sig fra Bush, er hans holdning til Iran (som hans holdning til Irak) hårdere end Bush-regeringens. Dette er, kan man roligt gå ud fra, McCains virkelige opfattelse, som han til tider udtrykker i et skarpt og humoristisk sprog ("Bomb, bomb, bomb, bomb, bomb 
Iran," sang han engang på et vælgermøde).

Føjer man hertil hans kritik af Bush-regeringens linje over for Nordkorea og hans opfordring til at smide Rusland ud af G-8, tyder hans holdning på en dyb og instinktiv uvilje mod at tale med sine fjender, der måske hidrører fra en bekymring for, at en sådan dialog kan opfattes som svaghed. Den viser også en iboende skepsis over for diplomati som et frontlinjevåben i USA's nationale sikkerhedsarsenal.

Selv om både Bush og McCain angriber Obama som svag, er Obamas holdning i virkeligheden tættere på den traditionelle grundholdning hos næsten alle, der nogensinde har praktiseret eller studeret diplomati eller udenrigspolitik. Selv trofaste McCain-republikanere som James Baker, Robert Gates (før han blev forsvarsminister), Henry Kissinger, og Brent Scowcroft har erklæret sig uenige med McCain i dennes holdning til Iran og Rusland.

Naturligvis er der ingen sikkerhed for, at alvorlige samtaler er mulige med Irans reelle magtcenter, den øverste leder ayatollah Ali Khamenei og hans inderkreds. Derfor er det, før man begiver sig ud på det diplomatiske spor, vigtigt at have en klar idé om, hvad der bør gøres, hvis forhandlingerne enten bliver afvist eller ikke gør fremskridt.

Kontakter bør begynde gennem private og yderst fortrolige kanaler med henblik på at afgøre, om der er grundlag for at gå videre. Den kommunikation, der for tiden er kommet i stand på lavt niveau mellem den amerikanske og iranske ambassade i Bagdad, er nok begrænset i omfang og hidtil ufrugtbar, men kan alligevel gøre det muligt at indlede sonderinger uden større risiko for at skulle indgå kompromiser, ligesom flere igangværende private 'to-spors'-bestræbelser også vil kunne vise sig nyttige.

\section{Model Nixon}

Den model, man først kommer til at tænke på, er ikke overraskende den, som præsident Richard Nixon og hans nationale sikkerhedsrådgiver, Kissinger, tog i brug for at indlede en dialog med Kina i 1971, efter 22 års afbrudte kontakter.

Nixons beslutning om at tale med et af de mest undertrykkende regimer i verden, på højden af kulturrevolutionens sindssyge, kom på et tidspunkt, da Beijings behandling af sin egen befolkning helt sikkert var værre end Teherans i dag. Kina støttede tillige de guerillastyrker, der kæmpede mod de amerikanske tropper i Sydøstasien.

Men Nixon og Kissinger talte med Mao Zedong - og ændrede verden. (Den fremgangsmåde, der ikke bør efterlignes, er Reagans tilbud i 1987, da han på højdepunktet af IranContra-dramaet i hemmelighed sendte sin nationale sikkerhedsrådgiver, Robert McFarlane, af sted til 
Teheran med en chokoladekage dekoreret med glasur i en form, der forestillede en nøgle.)

Vil en indsats for dialog med Iran skabe resultater? Kan den reducere den iranske regerings åbenlyse Israel-fjendtlige aktiviteter, der udgør en eksistentiel trussel mod den jødiske stat? Vil den kunne stoppe det iranske atomprogram? Er der tilstrækkeligt fælles grundlag til at inddrage Iran i et regionalt projekt til at stabilisere Irak og Afghanistan?

Ingen af disse spørgsmål kan besvares på forhånd, men de fleste videnskabsmænd og eksperter mener, at der er tilstrækkeligt med sammenfaldende interesser til at muligheden er værd at undersøge, sådan som Obama (og alle de andre kandidater til Demokraternes nomineringsvalg) har foreslået. Kombineret med truslen om skrappere sanktioner - og uden at tage en mulig magtanvendelse af bordet - vil denne gulerod og pisk-fremgangsmåde hverken truer sikkerheden, Israel eller USA.

Og den vil uanset dens udfald kunne styrke USA's position i verden andre steder, især i forhold til andre muslimske stater

Hvis Teheran afviser en mulighed for at føre meningsfulde samtaler med Washington, vil det øge sin egen isolation og sætte sig selv under større internationalt pres, mens USA vil forbedre sin egen stilling.

Naturligvis vil denne kurs, når den først er indledt, kræve justerin- ger hen ad vejen. Diplomati er ligesom jazz - en improvisation over et tema. Lad forsøget blive afprøvet næste år som en del af en ny udenrigspolitik, så at diplomati, som gennemføres med fasthed og bakkes op af USA's magt i overensstemmelse med amerikanske værdier kan genindtage sin traditionelle plads $i$ USA's nationale sikkerhedspolitik.

En sådan fremgangsmåde over for Iran, kombineret med tilbagetrækning af de amerikanske kampenheder i Irak, ville have en væsentlig yderligere fordel: Den vil øge værdien af, at USA vender tilbage til sin rolle som en seriøs og aktiv fredsmager i forholdet mellem israelere og palæstinenserne.

Som med så mange andre spørgsmål har Bush-regeringen spildt de fleste af sine otte år ved at forsømme denne konflikt, som den først i slutningen af 2007 begyndte at engagere sig i med 'Annapolis-processen', som blev iværksat af udenrigsminister Condoleezza Rice. Denne indsats vil i bedste fald, før Bushregeringens tid løber ud, ikke føre til andet end en løs rammeaftale.

Den næste præsident må engagere sig personligt i dette spørgsmål, som alle præsidenter fra Nixon til Bill Clinton tidligere har gjort det.

\section{Den anden krig}

Selv om både Obama og McCain er enige om betydningen af 'den anden krig' - den, der udkæmpes i Af- 
ghanistan - er dette ikke nok i sig selv. Den nuværende amerikanske politik i Afghanistan er en fiasko.

De amerikanske vælgere burde have hørt mere om, hvad de to kandidater vil gøre ved det. For McCain må spørgsmålet være, hvorfra de ekstra ressourcer, der er nødvendige, skal komme, hvis han vil fortsætte krigen i Irak. Obama har allerede givet tilsagn om mindst 10.000 flere soldater.

Siden den amerikansk ledede koalitions første succes med at fordrive Taleban fra byerne er den grundlæggende amerikanske plan om en tidsramme i Afghanistan igen og igen blevet forpurret af begivenheder, som ikke var forudsete, og af en politik, der var uhensigtsmæssig.

I det seneste år er katastrofen kun blevet afværget med indsættelse af supplerende britiske, canadiske, franske og amerikanske tropper. Den rette kurs nu vil ikke ligge i en enorm forøgelse af antallet af NATO-styrker, selv om yderligere styrker vil være nødvendige i den sydlige og østlige dele af landet.

Taleban kan ikke vinde i Afghanistan. Deres terrortaktikker og minderne om 'de sorte år' afskrækker de fleste afghanere.

Men ved at fortsætte krigen uden at tabe og ved at forblive i live og skabe vedvarende problemer kan Taleban nå vigtige mål: De kan hindre centralregeringen i at få succes, binde et stort antal af NATO-tropper og tiltrække 'jihadier' fra hele verden til en fjern, men sælsomt romantisk front.

Stillet over for denne udfordring har centralregeringen vist, at den ganske enkelt ikke selv kan varetage jobbet. I mellemtiden udretter det internationale samfund og en stor og ukoordineret blanding af ikkestatslige organisationer, internationale organisationer og bilaterale organisationer en mængde godt, men undergraver paradoksalt nok undertiden deres egne mål ved at skabe en stadig dybere afhængighed af, at udlændinge yder de tjenester, som Kabul ikke kan levere.

Situationen i Afghanistan er langt fra håbløs. Men som krigen går ind $\mathrm{i}$ sit ottende år, bør amerikanerne fortælle sandheden: Det vil vare lang tid - længere end USA's længste krig til dato, den 14-årige konflikt (1961 - 75) i Vietnam. Succes vil kræve en ny politik med hensyn til fire store problemområder: stammeområderne i Pakistan, narkobaronerne, som dominerer det afghanske system, det nationale politi og inkompetencen og korruptionen i den afghanske regering.

\section{Islamabad}

Alle disse aktuelle udfordringer er uhyre vanskelige, men den vanskeligste af dem vedrører de fristeder, som oprørerne nyder godt af i stammeområderne i det vestlige Pakistan. Afghanistans fremtid kan ikke blive sikret ved en oprørsbekæmpel- 
ses-indsats alene. Det vil også kræve regionale overenskomster, der giver Afghanistans naboer et medansvar. En aftale vil skulle omfatte Iran såvel som Kina, Indien og Rusland. Men den vigtigste nabo er naturligvis $\mathrm{Pa}$ kistan, som kan destabilisere Afghanistan efter behag - og har gjort det. At finde den rette politik over for Islamabad vil blive helt afgørende for den næste regering - og meget vanskeligt.

Den fortsatte forværring af situationen i stammeområderne udgør en trussel, ikke blot mod Afghanistan, men også mod Pakistans nye sekulære demokrati og stiller den næste præsident over for en ekstraordinær udfordring. Som det for nylig hed i en artikel i New York Times: "Det står i stigende grad klart, at Bush-regeringen forlader sin post i en situation, hvor al-Qaeda har faet held til at flytte sin base fra Afghanistan til Pakistans stammeområder, hvor det har rekonstrueret en stor del af sin evne til at angribe og kommunikere sine budskaber ud til militante $\mathrm{i}$ hele verden."

Intet - end ikke Irak - udgør nogen større politisk fiasko for den afgående regering.

\section{Overfyldt dagsorden}

Der er her sat fokus på nogle få store problemområder, men det betyder ikke, at andre kan blive ignoreret. Hvis man kan lære noget af historien, så er det, at problemer, som er blevet forsømt alt for længe, har det med igen at presse sig frem på den politiske dagsorden - Somalia, Bosnien, Cambodja, Darfur, Myanmar (også kendt som Burma), Tibet og Zimbabwe er blot nogle af de seneste eksempler.

Selv om en ny regering lægger ud med at koncentrere sig om føromtalte kritiske halvmåne, må den således også være meget opmærksom på de problemer, der ellers let risikerer at overvælde den, omtrent på samme måde som Rwanda kom bag på Clintons regering i 1994, da præsidentens fokus var på Bosnien.

Et godt eksempel er Sudan, hvor der ud over den indtrådte forværring af krisen i Darfur, også er det problem, at den Nord-Syd-aftale, som blev udråbt som en ægte Bushæra-succes, nu står i fare for at gå i opløsning. Det er sandsynligt, at dens centrale bestemmelse (nationale valg efterfulgt af en folkeafstemning om uafhængighed i syd) vil blive ignoreret eller afvist.

Risikoen er overhængende for, at Sudan inden 2010 igen vil eksplodere i en større nord-syd konflikt, med vedvarende fare for inddragelse af nabolande.

At forhindre et sådant scenario vil kræve intense bestræbelser under ledelse af USA og Den Afrikanske Union og vil kræve aktiv deltagelse og støtte fra Kina.

De Forenede Staters forbindelser med den muslimske verden vil kræve særlig opmærksomhed. Bestræ- 
belserne på at anspore moderate muslimer til at modarbejde ekstremisterne har ikke virket. En ny, kreativ tilgang til det offentlige diplomati skal udvikles. Hertil kommer det ejendommelige problem, som de seneste seks års 'demokrati-agenda' udgør. Bush-regeringens kluntede advokatur for denne grundlæggende menneskerettighed har inficeret et af nationens mest hellige begreber.

\section{Demokrati og menneskerettigheder}

Bush gjorde drømmen om demokrati en bjørnetjeneste ved at knytte den sammen med USA's militære magtmanifestationer. At presse andre lande til at indføre de overfladiske aspekter af et komplekst og subtilt regeringssystem, er simpelthen ikke den rette vej at følge for at fremme amerikanske værdier eller sikkerhedsmæssige interesser.

Alligevel er målsætningen korrekt og bør ikke opgives - blot præsenteres i en stil og en tone, der er langt mere følsom over for, hvordan den vil blive opfattet $i$ andre lande.

Den næste regering bør fokusere mere på menneskerettigheder (et begreb, der er sært fraværende i Bushs leksikon) og grundlæggende menneskelige behov, samtidig med at den fortsat søger at fremme udviklingen af demokratiske regeringsformer, ledsaget af udviklingen af en pluralistisk politisk kultur, retsstaten, og forbedringer i materielle betin- gelser, navnlig gennem jobskabelse.

Hvis der sker fremskridt på disse områder, vil demokratiet følge af sig selv, men på en måde, som disse lander selv bestemmer - med USA's opmuntring. Det er læren fra Chile, Indonesien, Filippinerne, Sydkorea, Taiwan, og flere lovende unge demokratier i Afrika.

Det var i Afrika, at præsident Bush kunne notere sin største succes hans anti-aids-program, som en af de få politikker, som har samlet et bredt politisk flertal i løbet af de sidste otte år. USA har brugt mere end 13 milliarder dollar på programmet siden 2003. Det har sparet langt over en million liv indtil videre og ansporet andre nationer til også at yde mere.

Men Bushs Afrika-politik har været bemærkelsesværdig mangelfuld i håndteringen af de strategiske, økonomiske og miljømæssige dimensioner ved Afrikas situation. Den har undladt at anvende statsmandskunstens instrumenter i håndteringen af Afrikas invaliderende voldsspiral - i Den Demokratiske Republik Congo, Sudan, Zimbabwe, og det obskure, men eksplosive Afrikas Horn. Verden har brug for en strategi for at løse Afrikas endeløse konflikter, og denne må omfatte en politisk metode til konfliktløsning.

Den næste regering skal deltage i krisehåndtering og mobilisere støtte fra sine allierede og fra Den Afrikanske Union. Bush-regeringen har spillet en nyttig rolle i den krise, som 
fulgte efter Kenyas valg (det samme gjorde Obama, som gav interviews til kenyanske medier og Voice of America), men ingen andre steder på kontinentet har USA været særlig effektiv.

FN er en central aktør, men USA bør føre an i en indsats for at få flere ressourcer til FN's fredsbevarende indsats i Afrika - i modsat fald vil sådanne bestræbelser ikke have nogen chance for succes. På Obamas ekstraordinære rejse til Afrika i 2006, gav han tidlige varsler om sit kandidaturs løfterige perspektiv.

Da jeg besøgte Kenya et par måneder senere, kunne jeg stadig føle den spænding hans besøg, herunder hans offentlige HIV-test i Nairobi, havde genereret. Den konventionelle visdom om Afrika er, at det er en håbløs sag. Dette synspunkt - hvilket svarer til at frasortere og dømme et helt kontinent ude - er hverken i overensstemmelse med sandheden eller moralsk, politisk eller strategisk acceptabelt.

\section{Latinamerika}

I Latinamerika må USA begynde med at afhjælpe den udbredte skepsis over for amerikansk lederskab men ikke ved at udstede lidet plausible løfter om at udrydde fattigdom og ulighed eller stoppe narkotikahandel og grasserende kriminalitet.

Det største bidrag den næste præsident kan give til at gennemføre den konsolidering af en social kon- trakt med Latinamerika, som har været så vanskelig at realisere, må begynde med at genoprette den sociale kontrakt i hjemlandet. Immigrationsreformer og politikker til at afhjælpe økonomisk ængstelse fra indførelse af universelle sundhedsydelser til støtte af investeringer i uddannelse og infrastruktur vil bane den sikreste vej til at genetablere offentlig støtte i USA til det, der nu er en de facto integration med Latinamerika, uanset om det er igennem kapital eller sprog, handel eller kultur.

For at fremme amerikanske interesser, har Washington behov for et nyt forhold til Mexico og for strategiske forbindelser med Brasilien. I Mexicos tilfælde vil den blomstrende handel langs den over $3.000 \mathrm{~km}$ lange grænse, det omfattende netværk mellem de to landes befolkninger og den fælles sårbarhed over for en stadig mere omsiggribende organiseret kriminalitet kræve vedvarende opmærksomhed fra Amerikas præsident, hvilket Bush da også har lovet, men ikke været i stand til at levere.

I Brasilien - verdens niendestørste $\varnothing$ konomi, en førende global producent af fødevarer og ethanol, en kommende råolie-gigant, en potentiel atommagt og en af de helt store udledere af drivhusgasser - kan den næste præsident finde en partner, som kan bistå med at fremme væsentlige globale initiativer, hjælpe med til at udforme multilaterale in- 
stitutioner, og fungere som en diplomatisk allieret, når de hårdeste regionale udfordringer skal løftes.

\section{Lederskab i en multipolær verden}

De Forenede Stater er ikke en hjælpeløs gigant, som kastes rundt på historiens have. Det er stadig den mest magtfulde nation på Jorden, og inden for visse grænser kan det stadig forme sin egen skæbne og spille den ledende rolle i en multipolær verden. Det kan stadig tage roret i løsningen af verdens mest presserende problemer (som præsident Bush gjorde effektivt på kun ét område, AIDS).

Der er mange problemområder, som venter på et inspireret, ja ædelt amerikansk lederskab, som bakkes op af oplyst amerikansk generøsitet, som også er i USA's egen interesse.
De Forenede Stater er stadig en stor nation. Den fortjener et lederskab, der er dens folk værdigt - et lederskab, som kan genskabe nationens stolthed og indgyde en følelse af et højere formål. Denne opgave må begynde i Amerika selv, men verden vil holde øje og venter.

Richard Holbrooke er amerikansk diplomat med tilknytning til Det Demokratiske Parti. Han var en af hovedarkitekterne bag de aftaler, som resulterede $i$ den endelige fredsaftale for Bosnien, Daytonaftalen, der blev underskrevet $i$ 1995, og han var USA's FN-ambassdør 1999-2001.

Trykt med tilladelse fra Foreign Affairs, der bragte artiklen $i$ september/oktober 2008 (volume 87, nr. 5).

Oversat af Niels Ivar Larsen. 